\title{
Decolonising the commercialisation and commodification of the university and theological education in South Africa
}

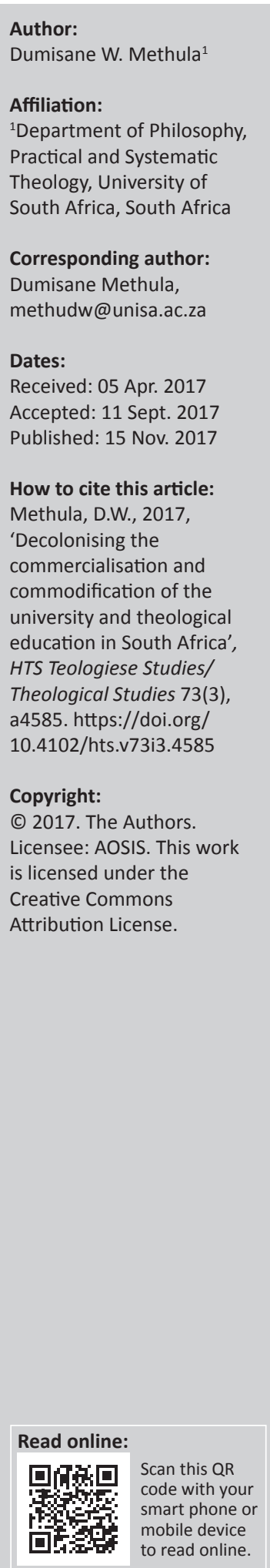

This article problematises the critical subject of the decolonisation of the university and theological education in South Africa from the neo-colonisation of commercialisation and commodification. The article, written from a decolonial perspective, serves as an epistemic critique of the cultures of corporatisation, rationalisation and entrepreneurship in higher education driven by the marketisation of society by the neoliberal institutions of globalisation. The article engages the role of decolonising theological education by drawing insights from African/Black theologies, the discourse on Africanisation and liberation to counter the strangulation and dominance of the commodification and commercialisation of theological education and prosperity theology in Africa, particularly in South Africa.

\section{Decolonising the commercialisation of the university}

Ndlovu-Gatsheni and Zondi (2016) point out that the decolonisation of the university means, among other things:

structural changes; curriculum change; epistemological paradigm shift from Eurocentric knowledge to Africa-centred knowledge; and a change of university cultures and systems that are alienating as well as increased and affordable access to education in general. (p. 4)

The urgent call for the decolonisation of the university curriculum by students in South Africa is inspired by the desire to break free from the stranglehold of the dominance of Eurocentric knowledge, obliterating capitalism, ontological dispossession and Africanising the curriculum. According to Sithole (2016a):

Decoloniality is deeply rooted in the genealogies of understanding which examine coloniality as long-
standing patterns of power that emerged as a result of colonialism and which define social, economic and
cultural conditions in absence of the colonial administration. This means coloniality is the result, survival,
metamorphosis, continuity and maintenance of subjection. (p. 109)

Coloniality thus is neocolonialism, neo-apartheid that creates institutional violence, inequality, injustice and exploitation under the false pretext of civilising mission, development and democracy in neocolonial contexts.

According to Mignolo (2012):

The words 'decolonial' and 'decolonisation' have been widely used since the second half of the twentieth century, during the Cold War, to describe the process of liberation mainly in Asia and Africa. 'Liberation' and 'decolonisation' were synonymous words. (p. 19)

In this article, 'decolonisation', 'liberation' and 'Africanisation' are synonymous words in the struggle to decolonise the commercialisation of the university. Decolonising the commercialisation of the university in the South African context gained momentum and public consciousness during the \#RhodesMustFall, \#FeesMustFall and \#AfrikaansMustFall campaigns.

The commercialisation and commodification of universities is the agenda driven by Bretton Woods Institutions that became dominant with the triumph of neoliberal socioeconomic discourse. The major problem with the commercialisation and commodification of the university is that it poses a serious threat to the future of in-depth research, quality scholarship and deep learning. Unfortunately, 'universities today are large systems of authoritative control, standardization, gradation, accountancy, classification, credits and penalties' (Mbembe 2016:29). The corporatisation, marketisation, innovation and entrepreneurial cultures have reduced universities to businesses of 
knowledge production. 'The World Bank has been one of the major culprits in spreading an objectivist and apolitical notion of "knowledge production"” (Stewart 2007:141).

Sound financial management, cost cutting measures, outsourcing and innovation are the buzzwords and play a decisive role in globalised economies in the management and governance of universities. This problematic episteme of reducing universities to institutions run and managed like industries produces incompetent, shallow and consultancy cultures that are non-academic by their very nature. According to Conradie (2011:425), to portray universities as businesses offering knowledge packaged and branded in the form of teaching programmes for sale to interested clients is highly reductionist. Conradie (2011:426) points out that 'Gaining knowledge involves more than purchasing products or acquiring skills; it also entails the deliberate process of developing disciplines and academic virtues that cannot be merely purchased on-line'.

The pursuit of knowledge must not be narrowly quantified in financial transactions and economic viability nor should it be bogged down to a consumerist quest for students viewed as interested clients in the dominant concept of the entrepreneurial university. The mandate of universities is not on producing too much information that is shallow, un-contextualised and lacks theoretical substance in research, tuition, teaching and community engagement. Tshaka (2014) laments:

the fact that universities across the globe seem to be duty bound to account for funding that they receive from governments of other countries places significant pressure on the humanities, of which theology as an academic discipline remains part of. It is this very same pressure that is instilling a culture of publish or perish in academics. (p. 2)

It is the view of this article that the culture of publish or perish is the agenda that is driven by the consumerisation, privatisation, individualisation and rationalisation of social sciences and humanities based on the mantra of innovation and entrepreneurial hegemonic discourses. Ndlovu-Gatsheni and Zondi (2016) opine that the:

forces of marketization and commodification of knowledge, the invasion of consultancy cultures, together with external and private funding that impose themselves on research agendas, massification of education as part of universalizing access for excluded and subaltern groups, and many others - there are South African specific challenges emanating from particular histories that need to be confronted head on. (p. 14)

This unfortunate situation compromises deep learning and in-depth research with the proliferation of shallow consumerist academic writings, the commodification of knowledge and creating a fertile ground for consultancy cultures where external and private funders impose their commercialisation agenda on research, tuition, learning and teaching.

The objective of this commercialisation of higher education and the commodification of scientific knowledge led by corporate managerialism with its intrusive bureaucratic and technocratic administrative systems seeks to exclude African epistemologies, pedagogies, genealogies and theologies and stifle the genuine transformation of the African university. This problem further entrenches the colonisation of the mind, informed by epistemicides (killing the knowledges of the colonised) and linguicides (killing languages and cultures of the colonised) and creating a dependency syndrome among academics from the subaltern cultures.

Mahmood Mamdani in his classic book, Scholars in the Marketplace, traces the market-based neoliberal reforms in African universities from the Makerere University, where the World Bank initiated the commercialisation of higher education. Mamdani (2007) points out that:

Privatisation was an external relationship between the market and the university, whereby the university opened up its gates to fee-paying students but did not change the curriculum to suit the demands of the market. Commercialisation, however, led to a deep-seated transformation, involving not only the external relationship between the university and the market, but also the internal process of knowledge production in the university and internal relations between different academic units. The university opened its gates to fee-paying students, commercialised relations between teaching units and embarked on changing its curriculum by introducing market-driven programmes. (pp. 118-119)

Mamdani (2007:5) further opines that commercialisation is the market that defines priorities in the functioning of a public university and the subversion of a public institution for private purposes. The privatisation and commercialisation of the university led to changes in the curriculum, introducing market-driven study programmes and the casualisation of academic labour. In addition, it creates tensions, mistrust and competition among colleagues and academic departments as they compete for students, access to funding and other resources. I agree with the observation made by NdlovuGatsheni (2016:45) that 'the emergence of corporate universities is in fact one of the most catastrophic developments in the current management of higher institutions'. Hence, Mbembe (2016:31) is correct when he says, 'to decolonize means to reverse this tide of bureaucratization' that came with the emergence of the corporate university.

\section{The decolonial perspective of the university}

In the struggle to decolonise university curriculum and liberate theological education, we must respond to the challenge put forward by Sithole (2016b) that:

African people are problematic as subjects because they are racialized, the very characterisation that puts them at the receiving end of epistemic racism. Epistemic racism is the exclusion of other knowledges, local/public histories, epistemologies and subjectivities which are said to fall outside the epistemological grid of universalism. (p. 214)

The biggest challenge facing African universities after the juridical end of colonialism and apartheid is epistemic racism 
that excludes African histories, epistemologies, subjectivities, in knowledge construction, dissemination and production under the false pretext of universalisation, rationality and objectivity as understood in the canon of Western thought.

\section{Sithole (2016b) correctly points out:}

the darker side of modernity constitutes racism, violence and destruction, all of which can be understood as subjection. Modernity is the site of castration of subjectivities and even not allowing the formation of political imaginations. (p. 216)

\section{Sithole (2016a) argues further to say:}

modernity spread globally, violating all forms of life on the other side of the abyssal line in order to redeem them from their barbarity to civility, while on the contrary, modernity is the axis of evil itself, as it does not create civility but barbarity par excellence. (p. 113)

The agenda of commercialisation as the agenda of modernity seeks to castrate African intellectual thought patterns and destroy African spiritualties; hence, commodifying theological education becomes violation of life.

\section{Lewis R. Gordon (2006) opines that:}

The rise of the academic managerial class has been, perhaps, the most catastrophic development in the modern university. [...] What is clear is that the academic managerial class, unlike past scholars who so happened also to administrate, no longer has knowledge as part of its telos. That class has folded onto itself as the object of its own preservation, and the result is its own proliferation. Faculties are up in arms at many universities at which administrators are now outnumbering them, and the avalanche continues as the phenomenon of graduate students pursuing doctorates without the aim of producing knowledge but directly to administration. (p. 10)

The rise of the corporate managerial elite has led to signs of stress and low morale among many academics, as administrators earn better salaries than academics. 'In the modern, neoliberal era, the academic role seems invisible to the corporate manager's eye' (Stewart 2007:132). As a result, 'many academics have become increasingly passive and reactive, rather than engaged and creative' (Stewart 2007:132).

The managerial elite in corporate universities have reinforced divine racism, epistemic apartheid, hermeneutic colonisation, patriarchal methodologies and predatory epistemologies:

Tracking the trajectory of the university one identifies the following shifts, informed by the mutating imperatives of modernist Western thought: the Renaissance university, Enlightenment, Kantian-Humboldtian university, and currently corporate university. (Ndlovu-Gatsheni 2016:35)

\section{Ndlovu-Gatsheni (2016) elaborates that the:}

corporate university began to replace the Kantian-Humboldtian university in the 1970s. It was imposed on Africa in the 1980s during the heydays of structural adjustment programmes and the triumphalism of neoliberalism. (p. 35)
The main drivers of this corporate entrepreneurial university in society, academia, religion and business are multilateral institutions of globalisation such as the World Bank, World Trade Organization and the International Monetary Fund. These multi-lateral institutions based in Euro-North America are driving the neoliberal, capitalist, technological and economic globalisation with catastrophic consequences for the developing countries, particularly in Africa. The problem with economic globalisation is that it creates inequality among nations, institutionalised violence, endemic poverty and environmental destruction and emphasises profits at the expense of common good and re-humanising the world.

This article is of the view that the colonisation of being, knowledge and power can be traced to the formal beginnings of the modern global system in 1492 . This era represents the formal introduction of structural racism with the colonisation of America, Asia and Africa. Grosfoguel (2007:213) defines 'modernity as a racially hierarchized, patriarchal, Christiancentric, Euro-North American-centric, hereto-normative, capitalist, colonial, and modern formation'. This modern world system has been anti-decolonisation, critical theories from the Global South, and subaltern methodologies from the periphery.

Ndlovu-Gatsheni (2016:41) says that the neoliberal rationality and coloniality of market relations gave birth to Westernised corporate universities, an epoch characterised by people worshipping at the altar of wealth accumulation and consumptionist cultures rather than knowledge production; this is an epoch of commodification and marketisation of education and knowledge. This means we must discard publications, analytical lenses, pedagogies and theories that are rooted in the coloniality of the markets in academia by shifting the geography of knowledge, power and being. I agree with Sithole (2016:110): ‘[e]pistemic colonisation occurred and is sustained by means of epistemic violence which wore the mask of Euro-American epistemology'. The violence of commercialisation and commodification of the university and theological education is perpetrated by EuroAmerican epistemology in the African continent.

\section{According to Ndlovu-Gatsheni (2016):}

the African university must consider fully embracing a decolonial epistemic perspective as a form of critical social theory informing its teaching and research, as this is in tandem with the agenda of liberation and charting sustainable development alternatives. A decolonial epistemic perspective is rooted in African resistance to such oppressive processes as the slave trade, imperialism, colonialism, apartheid, and neo-colonialism, as well as the disempowering effects of the globalisation process. (p. 42)

Embracing decolonial epistemic perspective as a critical social theory will 'disrupt, question, displace, rattle, and unsettle the guardian of the status quo that is, qualitative, quantitative and triangulation methodologies' (Sithole 2016:216b). If we are to privilege the struggle against corporatisation, marketisation and consumerisation of higher education, then we must disrupt, question and unsettle these academic methodologies 
and theoretical approaches that normalise, institutionalise and naturalise the beast of modernity. This then means that in Africa we cannot solve the problem of the privatisation, rationalisation and corporatisation of higher education by privileging European theoreticians like Karl Marx, Karl Barth, Paul Tillich, Antonio Gramsci and others for their writings merely reflect dialogue with modernity or coloniality.

\section{Black and African theologies}

It is imperative for African and Black theologies of liberation as decolonial episteme to counter the commodification of theological education by appealing to the rich heritage of inculturation, indigenisation, decolonisation, contextualisation and liberation. The reason being to foreground theological education among the living experiences of African people which are characterised by the dispossession of land, humanity and labour of African people in training future church leadership for ministry and theological leadership in academia.

According to Maluleke (1997:6), '[f]or nearly half a century, Africans have attempted to articulate their own brands of Christian theologies consciously and deliberately'. The emergence of African theology after the Second World War period was not only a call for the decolonisation, inculturation and indigenisation, but also a theoretical and intellectual radical revolutionary protest against the strangulation, domination and enslavement of Western philosophical, scientific and theological discourses that were foreign to the existential, religious and cultural identities of Africans. At the socio-political and economic levels, the challenge posed by African theology as a cultural hermeneutic of liberation served as a critique of liberal theology that concerned itself with answering the questions of unbelievers in middle- and upperclass societies of Europe and North America, whereas African and Black theologies as part of the developing countries theologies dealt with the questions of non-beings, the questions of race, culture and gender in the zones of non-beings.

Black theology as a decolonial intervention is a spiritual counterpart of Black Power and Black Consciousness Movement that proclaims the spiritual, ontological and psychological liberation of black people from political subjection, spiritual enslavement, economic oppression and the racism of the white Christian church and its neocolonial apartheid theology, which is perceived as a heresy and pseudo-gospel. It is imperative for the Black/African Christian Church and Black theology to subject every economic system (including commercialisation and commodification) to the demands of the gospel based on human rights, human dignity, a just social order and a shared vision for development, common good, based on liberation, justice, shalom and the Reign of God (Methula 2014:113).

Naidoo (2016a) makes a practical theological intervention, stating:

Within theological education what we find is the entrepreneurial marketing of education; valuing the student in terms of what they consume or produce in the supermarket of theological offerings where education is viewed and treated as a commodity. (p. 1)

The reason being the spiritual formation of future church leaders in seminaries, colleges, bible schools and universities still serves the capitalist, elite interests and the scientific, epistemological and biblical/gospel interests of the white people and their neocolonial agenda. I concur with Naidoo (2016b) that there is too much:

emphasis on health, wealth, promotion, privilege, and power in the gospel of prosperity in parts of Africa, has become a major challenge facing the church today due to the dominant value of consumerism. (p. 1)

The phenomenon of the materialisation of spirituality, the commercialisation of the church and the commodification of religion leads to the unethical and immoral practice of the monetisation of faith and blessings. According to Okoli and Uhembe (2014):

religion is a big business, a big-time employer of labour, and super income generator. The sacred endowments and spiritual providence of religion are highly commercialised and consumerized. Hence, sacramental, spiritual books, and CDs are no longer necessarily produced to edify and uplift the 'souls of the faithful'; rather, they are designed expressly for material profiteering. In this commercialisation of faith, obedience to God's will counts minimally what counts more is the size of the offering that opens doors to heaven. (p. 601)

In the church and broader society, we must critique and problematise the emergence and dominance of:

spiritual materialism that is a manifestation of 'queer capitalist tendency' in the context of the contemporary global market economy order, characterised by excessive consumerism, commercialisation, monetization, and marketization of the wider society. (Okoli \& Uhembe 2014:595)

African and Black theological education must prophetically speak against the commercialisation and commodification of the church by prosperity preachers that normalises, naturalises and institutionalises 'queer capitalist tendencies' that are characterised by excessive commercialisation of the sacred, commodification of grace, prayer and offering. While there is nothing wrong with seeking health, wealth, power, promotion and blessings, the only problem is that church members pay thousands of Rands to get a breakthrough at work, in the business and to receive healing. The materialisation of the spirituality and religion becomes problematic because it is characterised by excessive materialism, commercialisation, commodification and monetisation of the church that is reduced to a consumerist church. Hence, there is the need to view education from the contributions of Pan-Africanist and Black Consciousness thinkers in South Africa.

\section{The agenda of Africanisation and liberation}

The founding president of the Pan Africanist Congress of Azania, Sobukwe (2010), once said: 
education means to us: the identification of ourselves with the masses. Education to us means service to Africa. In whatever branch of learning you are, you are there for Africa. You have a mission; we all have a mission. A nation to build, a God to glorify, a contribution to make clearly towards the blessing of [hu] mankind. (p. 6)

Therefore, generally speaking, education means identifying with the poorest of the poor, making a preferential option for the poor and being there to solve Africa's sociocultural problems. Abram Ongoposte Tiro, the student leader of the Black Consciousness Movement, who was killed in a letter bomb by the apartheid regime in Botswana in 1974, said, 'If your education is not related to the liberation of Africa it is meaningless' (Tiro 1972:2). Tiro perceived education as liberation, decolonisation and Africanisation, which means service to humanity and the liberation of African people.

According to Maluleke (2006:72), 'Africanization is about liberation the comprehensive liberation of all Africa and all Africans but more especially the poor, liberation is the main criterion and goal of all Africanization'. Maluleke (2006:73) opines, 'Africanization of Theological Education will therefore entail an honest but critical appraisal of all so-called African traditions and cultures against the criteria of their liberational import'. In this article, 'Africanisation' is synonymous with 'liberation', 'decolonisation' and 'indigenisation". The black church as the body of Christ, the people of God and the creation of the Holy Spirit that proclaims the kerygma of the Kingdom of God must always prophetically and apostolically speak against the consumerism, corporatisation, commercialisation, monetisation, marketisation and commodification of society, higher education and theological education in our sexist, racist and classist societies.

African subjects in academia must restore the lost dignity and dismembered histories, pedagogies, sciences and epistemologies of Africa that were destroyed by settler colonialism. Kaunda (2015) asks:

[the] question is, in what ways can theological education become a decolonial instrument for counteracting the colonisation of the mind made possible through materio-spirituality-centred thought that counters the worst excesses of alienation, disengagement and estrangement? In this historical epoch characterised by disembowelling commercialising, commodifying and corporatist capitalist agendas the imperative of the decolonisation of the mind should be a top priority on the agenda of theological education. (p. 75)

The decolonisation, Africanisation and liberation of theological education must be informed by 'the need for reconstructing theological education in the African context as the overall character of much theological education is overwhelmingly Western and Eurocentric' (Naidoo 2016b:5). Tshaka (2016) also emphasises this point:

Current theological education is Western in its very nature. There is a particular history to why this Western outlook, also found in theological education, has remained unchecked.
Primarily, the reason for the continued hegemony of Western forms of knowledge production is a result of the inherent disregard that those in the West had for Africa and her purported inability to produce 'true knowledge'. The Christian faith is no stranger to this indictment on Africa and her people. (p. 92)

What Naidoo and Tshaka mean is that Christian theological education in Africa has been spiritually, culturally, psychologically and epistemologically colonised, hence the continued hegemony of Euro-North American forms of knowledge. This further means that the theological studies must critically engage the epistemic discourse of theological education, unmask the agenda of modernity as coloniality and explore alternatives to the crisis of capitalism and disciplinary decadence so prevalent in social sciences and humanities. Theological education particularly in South Africa must take seriously the challenge put forward by Maluleke (2006):

Where and when Africanization has been perceived as necessary it has tended to be framed in terms of 'constituency-building' rather than in terms of astute and deliberate choices of interlocutors. In this case Africans/Blacks are targeted as 'costumers' and 'consumers' of theological education rather than as interlocutors. On the basis of these costumer and consumer driven considerations, Africanization becomes a cosmetic enterprise. (p. 69)

In our attempts to decolonise and Africanise theological education, we must be careful of the neoliberal rhetoric that targets Africans as costumers and consumers of theological education while taming their subjectivity, agency and leadership as independent interlocutors.

\section{The reason being:}

we must engage the subject of theological education at a time when Christianity is gravitating towards the global South, confirms the view that the struggle today is concerned, particularly, with the curricula of theological education. It is this struggle that justifies the question of the Africanization of theological curriculum. (Tshaka 2016:92)

In training future church leaders for ministry and societal responsibilities, Naidoo (2015:5) insists that we must take into consideration the transformative remedies that decolonise and manage diversity by developing 'pedagogical strategies rooted in the anti-racist discourses [that] place emphasis on critical thinking as the foundation, new meaning construction, self-discovery, and self-creation against the legacies of prejudice and alienation'. As we develop anti-racist discourses in theological education, we must take seriously the ontological and phenomenological questions of blackness and Africanness that will lead to decolonial theologising and the creation of new humanity and liberate theological scholarship from the strangulation of commercialisation and commodification of the university and theological education.

Ramantswana (2016) correctly suggests that the best way to decolonise theological and biblical education is: 
Those who are on the underside of modernity need to engage in a process of Mignolo's 'delinking from the web of imperial/ modern knowledge and from the colonial matrix of power', in order to regard the Euro-Western systems as insufficient, that is, not applicable to everyone everywhere (Mignolo 2007, 2009). This implies the rejection of the tendency to claim 'universality' for Western categories, which the rest have to mimic in their social locations. Thus, delinking is an epistemic shift from the imposed colonial mindset and the continuing dependence on Euro-Western categories. (p. 189)

Theological education must be delinked from the imperial/ modern claims of universality that continue epistemic colonisation and the global matrix of power towards relinking with African thought patterns rooted and grounded in Ubuntu, communalism and care for the environment. I concur with Odora Hoppers (in Higgs 2015):

The African voice in education at the end of the twentieth century is the voice of the radical witness of pain and inhumanity of history, the arrogance of modernisation and the conspiracy of silence in academic disciplines towards what is organic and alive in Africa. (p. 44)

Higgs (2015:45) confirms this point by stating that 'all educational discourses in Africa, including those in theological education, should have Africa as their focus, and as a result be indigenous-grounded and orientated'. Fanon pleads emphatically that 'let us not pay tribute to Europe by creating states, institutions, and societies which draw their inspiration from her' (Fanon 1961:254). If theological education in Africa seeks to create new humanity, then she must not model her universities, curricula, methodologies, epistemologies and pedagogies from the Euro-North American agenda of commercialisation and commodification.

As a devoted Pentecostal-Charismatic pastor who attended prosperity churches from 1992 to 2007 till I opened my Pentecostal congregation, my theological outlook was largely influenced by prosperity preachers such as TD Jakes, Joel Osteen, Musa Sono, David Odebayo and others. I listened to their inspirational, motivational and encouraging messages on Trinity Broadcasting Network every morning and every night till I realised that though they can inspire and motivate, the problem is they leave you without a desire and passion for social justice, structural transformation and overcoming the evils of capitalism. I agree with Bayart (in Obadare 2016):

Pentecostalism sings the praises of material success, a sign of sanctification and liberation from the feelings of jealousy that motivate witches. It emancipates the individual by hailing his personal ascent, blesses capitalist accumulation and the relation to merchandise, and 'armour-plates' believers against the menacing world of the invisible. In this respect, it inverts the 'equation that linked wealth to evil-doing and poverty to sanctity. (p. 2)

There is a need to seriously decolonise the Pentecostal church as it has fundamentally deviated from the 1906 Azusa Street Revival led by William Seymour, the black revivalist preacher. The neoliberal agenda, elite pact and capitalist miracle workers have captured the Pentecostal church and her liberation theology through prosperity pseudo-preachers only concerned with their narrow individual success and personal well-being. In this context, the work by the Commission for Religious and Linguistic Rights (CRL) on the Commercialisation of Religion was a breath of fresh air:

However, the recent controversial news reports and articles in the media about pastors instructing their congregants to eat grass and snakes, to allegedly drink petrol or to part with considerable sums of money in order to be guaranteed a miracle or blessing has left a large portion of society questioning whether religion has become a commercial institution or commodity to enrich a few. (CRL Report 2016:3)

There is a need for theological education for all those intending to join ministry as pastors to be trained to avoid instances of church members being told to eat rats, snakes and drink petrol. We must decolonise and deconstruct the Pentecostal church and her theology within the African context:

The similarities between neoliberalism and Pentecostalism go even further, so much so that it is not unreasonable to suggest that, so far as prosperity is the raison d'etre of neoliberalism, Pentecostalism may rightly be seen as its religious mode or extension. Borne on the wings of globalisation, neoliberalism and Pentecostalism have travelled fast, far and wide, spreading the same gospel of material success through individual responsibility. And each, at least in its own way, celebrates the miraculous - in one, the miracle of the heroic all-conquering selfrepossessed; in the other, the sheer magic of what Pentecostals like to call 'divine favour'. (Obadare 2016:4)

We must decolonise the church from prosperity theology, individual success, elite preaching and capital accumulation. In addition, fly-by-night Bible schools and theological seminaries that offer fast-food theologies that are uncontextualised, shallow and non-academic by their very nature must be exposed and regulated by the South African Qualifications Authority. Their theological programmes must be in line with the policies of the National Qualifications Framework to ensure that they comply with the law and authorities governing education in the country.

\section{Conclusion}

This article has problematised the subject of the decolonisation of higher education and theological education in Africa, but particularly in South Africa, from the neo-colonisation of commercialisation and commodification. The rationalisation, corporatisation and innovation cultures in higher education have compromised the quality of deep research, informed tuition and in-depth teaching with shallow scholarship and emphasis on knowledge production measured in monetary terms. This agenda is driven by the triumph of neoliberal trajectory in academia, society and religion. I applied a decolonial approach to unmask the Euro-American modern agenda that has undermined the philosophies, genealogies, epistemologies and pedagogies from subaltern cultures. Moreover, I proposed that African and Black theologies could rescue us from the strangulation of the commercialisation 
and commodification of theological education. Thus, I conclude by stating that the primary purpose of education is to solve social problems, not to maximise profits, and to generate knowledge that liberates humankind from epistemic colonisation, spiritual enslavementand social marginalisation. Theological education in Africa and South Africa must produce graduates who can serve as public intellectuals, thought leaders, forces for social change and agents of transformation in all spheres of socioeconomic and religiocultural aspects of life. Hence, theological education must be decolonised and Africanised particularly within the South African neoapartheid context.

\section{Acknowledgements Competing interests}

The author declares that he has no financial or personal relationships which may have inappropriately influenced him in writing this article.

\section{References}

Commission for the Promotion and Protection of the Rights of Cultural, Religious and Linguistic Communities (CRL Rights Commission), 2016, CRL rights commission's preliminary report of the hearings on commercialisation of religion and abuse of people's belief systems, CRL Commission, Johannesburg.

Conradie, E.M., 2011, 'Knowledge for sale? The impact of a consumerist hermeneutics on learning habits and teaching practices in higher education', Koers 76(3), 423446. https://doi.org/10.4102/koers.v76i3.36

Fanon, F., 1961, The wretched of the earth, Penguin Books, London.

Gordon, L.R., 2006, Disciplinary decadence: Living thought in trying times, Paradigm Publishers, Boulder, CO.

Grosfoguel, R., 2007, 'The epistemic decolonial turn: Beyond political-Economy paradigms', Cultural Studies 21(2-3), 211-223. https://doi.org/10.1080/0950 2380601162514

Higgs, P., 2015, 'The African renaissance and the decolonisation of theological education', in M. Naidoo (ed.), Contested issues in training ministers in South Africa, pp. 43-56, SUN Press, Stellenbosch.

Kaunda, C.J., 2015, 'The denial of African agency: A decolonial theological turn', Black Theology 13(1), 73-92. https://doi.org/10.1179/1476994815Z.00000000048

Maluleke, T., 1997, 'Half a century of African Christian theologies: Elements of the emerging agenda for the twenty-first century', Journal of Theology for Southern Africa 99, 4-23.

Maluleke, T., 2006, 'The Africanization of theological education: Does theological education equip your sister?', in E.P. Antonio (ed.), Inculturation and postcolonial discourse in African theology, pp. 61-74, Peter Lang, New York.

Mamdani, M., 2007, Scholars in the marketplace: The dilemmas of neo-liberal reform at Makerere University, 1989-2005, CODESRIA, Dakar.
Mbembe, A., 2016, 'Decolonizing the University: New directions', Arts \& Humanities in Higher Education 15(1), 29-45. http://doi.org/10.1177/1474022215618513ahh. sagepub.com

Methula, D.W., 2014, 'Engaging in the struggle for economic justice in the streets of the city of Tshwane', Missionalia 42(1/2), 107-119.

Mignolo, W., 2012, 'Decolonising western epistemology: Building decolonial epistemologies', in A.M. Isasi-Díaz \& E. Mendieta (eds.), Decolonising epistemologies: Latina/o theology and philosophy, pp. 19-43, Fordham University Press, New York.

Naidoo, M., 2015, 'Transformative remedies towards managing diversity in South African theological education', HTS Teologiese Studies/Theological Studies 71(2), Art. \#2667, 1-7. https://doi.org/10.4102/hts.v71i1.2667

Naidoo, M., 2016a, 'Overcoming alienation in Africanising theological education', HTS Teologiesie Studies/Theological Studies 72(1), Art. \#3062, 1-8. https://doi. org/10.4102/hts.v72i1.3062

Naidoo, M., 2016b, 'The commercialisation and commodification of theological education in Africa', Call for papers to host the Conference of The Commercialisation and commodification of theological education in Africa, 14-16 September 2016, University of Pretoria, Pretoria.

Ndlovu-Gatsheni, S.J., 2016, 'The imperative of decolonizing the modern Westernised University', in S.J. Ndlovu-Gatsheni \& S. Zondi (eds.), Decolonising the University, knowledge systems and disciplines, pp. 27-45, Africa Carolina Academic Press, Durham, North Carolina.

Ndlovu-Gatsheni, S.J. \& Zondi, S., 2016, 'Introduction: Coloniality of knowledge: Between troubled histories and uncertain futures', in S.J. Ndlovu-Gatsheni \& S. Zondi (eds.), Decolonising the University, knowledge systems and disciplines, pp. 3-24, Africa Carolina Academic Press, Durham, North Carolina.

Obadare, E., 2016, 'Raising righteous billionaires': The prosperity gospel reconsidered', HTS Teologiese Studies/Theological Studies 72(4), a3571, 1-8. https://doi. org/10.4102/hts.v72i4.3571

Okoli, A.C. \&Uhembe, A.C., 2014, 'Materialism and commodification of the sacred: A political economy of spiritual materialism in Nigeria', European Scientific Journal 10(14), 595-606.

Ramantswana, H., 2016, 'Decolonising biblical hermeneutics in the (South) African context', Acta Theologica 2016 (Suppl 24), 178-203. https://doi.org/10.4314/ actat.v36i1.11S

Sithole, T., 2016a, 'A decolonial critique of multi-inter-transdisciplinary methodology', in S.J. Ndlovu-Gatsheni \& S. Zondi (eds.), Decolonising the University, knowledge systems and disciplines in Africa, pp. 107-130, Carolina Academic Press, Durham, North Carolina.

Sithole, T., 2016b, 'Researching the African subject in Africa Politics', in S.J., NdlovuGatsheni \& S. Zondi (eds.), Decolonising the University, knowledge systems and disciplines in Africa, pp. 213-237, Carolina Academic Press, Durham, North Carolina.

Sobukwe, M.R., 2010, The speeches of Robert Sobukwe, Pan Africanist Congress of Azania, Head Office, Johannesburg.

Stewart, P., 2007, 'Re-envisioning the academic profession in the shadow of corporate managerialism', JHE/RESA 5(1), 131-147.

Tiro, O.A., 1972, Graduation speech by Onkgopotse Tiro at the University of the North, 29 April 1972, viewed 01 February 2016, from http://www.sahistory.org.za/ archive/graduation-speech-onkgopotse-tiro-university-north-29-april-1972

Tshaka, R., 2014, 'On being African and reformed? Towards an African reformed theology enthused by an interlocution of those on the margins of society', HTS Teologiese Studies/Theological Studies 70(1), Art. \#2070, 1-7. https://doi. org/10.4102/hts.v71i2.266

Tshaka, R., 2016, 'How can a conquered people sing praises of their history and culture? Africanization as the integration of inculturation and liberation', Black Theology An International Journal 14(2), 91-106. https://doi.org/10.1080/14769 948.2016.1185841 